Malika Maksatovna Knissarina, K.Zh. Aganina,

Muslima Abdykarimovna Bashbayeva,

Yuliya Zame, Yerksh Shaikhimov

Kazakhstan

\title{
Development of Regulatory Skills in Younger School Pupils
}

DOI: 10.15804/tner.2016.44.2.13

\begin{abstract}
The article presents a solution for one of the significant tasks in pedagogical science and practice, namely the development of regulatory skills in younger school pupils as a significant factor of their educational and cognitive competence development. The aim of our study was to conduct practical evaluation of the proposed program of the development of regulatory skills in younger school pupils. Scientific novelty consists in the created program of the development of regulatory skills in younger school pupils, which generally allow for increasing education and cognitive competence, which is the basis for pupils' functional expertise, in accordance with the aims and tasks of the state-significance documentation. The study used logical and historical analysis of scientific literature on the topic, pedagogical observation, a survey, questionnaires, testing and a pedagogical experiment. Based on the obtained results, we developed educational and methodological recommendations for teachers on the topic of developing regulatory skills in young school pupils, as an elective class program for $2^{\text {nd }}$-grade pupils.
\end{abstract}

Keywords: learning skills, development, educational and cognitive competence, regulatory skills, level of regulatory skills in younger school pupils, self-management, regulatory cycle, educational management, interschool management, game-technical management, younger school pupils time management 


\section{Introduction}

We are faced with the problem of efficient development of school pupils' functional expertise as a characteristic of the whole nation's ability to compete. National education shows a tendency towards moving the education content to the level of key and object competences and pupils' functional expertise, which is written in the State program for the education development in 2011-2020 and the National plan of actions on pupils' functional expertise development in 2012-2016 of June $25^{\text {th }} 2012$, \#832 (State general-mandatory standard for secondary education, 2012).

The result of functional expertise development is pupils' mastering of the key competence system, which allows young people to efficiently apply the acquired knowledge in practice and use it successfully during the social adaptation process. Key competence is the state's requirement towards the personality qualities of a secondary school graduate, presented as the education results and defined by the State educational standards and education programs.

The following competences of the key competences in primary school graduates are relevant to our study:

- regulatory competences (the ability to solve problems);

- informational competences (the capability of conducting independent cognitive activity and life-long studying);

- personality competences (the capability of self-organization, self-improvement, gaining life - and professional self-actualization and being tolerant).

American scientists, K. Pribram, E. Galanter and G. Miller, stated that "Educational activity is cognitive by its nature. Because of this, its organizational and psychological structure includes motivation, problem (learning situation or learning problem in the shape of a task), execution (realization in the form of learning actions), control and evaluation, which transfer to self-control and self-evaluation" (Shiyanov, E.N., Kotova, I.B. 1999).

In our study, we define educational and cognitive competence, as we have stated before, as the pupil's mastering of a complex procedure, which integrates a number of inter-connected conceptual orientations, knowledge, skills and abilities and allows for efficient conducting the self-regulating activity of solving real educational and cognitive problems (Knisarina, 2015). Interestingly, international scientists define self-regulation as the most significant condition of life-long learning organization (studies by S. Dietrich, S. Kraft, J. Reischmann, and others); they study the conditions and ways of self-regulated education of the youth (studies by P. Faulstich, H.F. Friedrich, F.E. Weinert, F.G. Deitering, and others). 
Our study is mostly based on the ideas and classification of pupils' general-educational abilities by D.V. Tatyanchenko and S.G. Vorovschikov, who define educational and cognitive activity as pupils' self-regulated activity of solving personally-significant and socially-relevant actual cognitive problems, which is accompanied by mastering the knowledge and skills on obtaining, processing and implying the information necessary for their solution (2003). It includes all educational regulatory activities, i.e., goal-setting, planning, prognosis, correction, control and evaluation.

The aim of our study was to evaluate the efficiency and consistency of the program for regulatory skills development in younger school pupils, which we created and developed. Our ideas are based on the fact that regulatory skills characterize the pupil's readiness to use them in typical and non-standard situations, understanding the goal, motive, structure and results of the educational and cognitive activity, to conduct a correct sequence of operations, which are a part of educational activity regulation action.

Because of this, the aim of the evaluated program for regulatory skills development in younger school pupils is their mastering of a number of fundamental regulatory skills based on the motivation and orientation of the activity (OBA) of educational activity regulation.

Educational goals of the Program:

- methodological training of primary school teachers for regulatory skills development in younger school pupils;

- actualization of the regulatory skills development system in younger school students in practice;

- cooperative work of teachers and parents on the present problem.

Regulatory skills that were developed correctly and on time are the condition for pupils' successful dynamics in school education and an efficient tool of their educational and independent activity.

The novelty of this study lies in the fact that scientifically grounded and proven research materials contribute to the development of the theory and practice of the formation of regulatory skills in younger school pupils:

- the concept of "regulatory skills in younger school pupils" and its structure with account for age specifics of children have been defined more exactly;

- a theoretical model which is formally presented by the Program for regulatory skills development in younger school pupils has been developed;

- objective links between the level of regulatory skills, subjectivity and success (personal, educational, professional) of younger school pupils have been identified; 
The system of work on the development of regulatory skills in younger school pupils may increase the subjectivity of students and make them successful.

The training materials presented in this paper (an elective course program, an exercise book and assignments, etc.) can be used by primary school teachers, subject teachers, methodologists and school psychologists in their practical work. The research results allow for improvement of the efficiency of the educational institutions for the organization of the adaptive educational environment aimed at the formation and development of regulatory skills in younger school pupils. The research results can be recommended for use in the practice of educational institutions, as well as in the system of training and retraining of educators.

\section{Experimental Methods and Materials}

According to the order from the Department of Education of Aktobe, during the expert council meeting on the scientific development of the city schools, the experimental base of the doctoral thesis study was defined to be set in the general-education schools \#\#12,13 and 22 of Aktobe, Western region of the Republic of Kazakhstan.

In order to confirm the Program consistency at the beginning and the end of the experiment we defined the following in the abovementioned schools:

- level of primary school teachers education in the field of regulatory skills development;

- level of regulatory skills in younger school pupils.

For this type of study we used the survey method, i.e., a written survey of a large number of people by survey sheets. The surveys were composed on the basis of theoretical development of open type (they imply an answer to a question). The survey method allows for obtaining a large amount of information in a relatively short period of time.

The method of the analysis of pedagogical (school) documentation provides objective data on the pedagogical process organization in the school. This method is used in order to define the correspondence of the educational programs and school documentation to the studied problem of regulatory skills development in younger school pupils.

Thus, at this stage of the study we mostly implied empirical methods of an applied-scientific group of methods. 


\section{Results}

The survey of the teachers during the experiment showed an insufficient level of theoretical and methodological education for regulatory skills development in younger school pupils (cf., Figure 1).

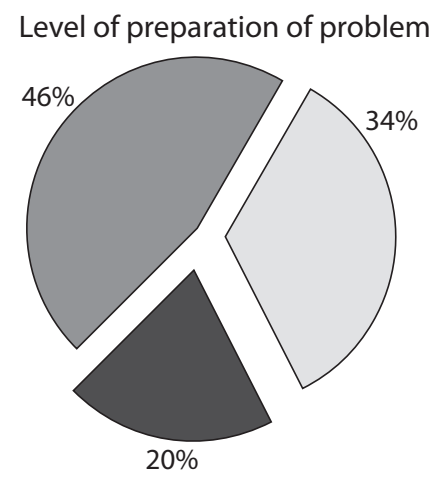

Figure 1. Results of the evaluation of the teachers' level of education for regulatory skills development in younger school pupils

Source: Based on the author's design

The results of the pupils' testing and their parents' survey at the beginning of the experiment confirmed the significance of the study problem: the level of regulatory skills in younger school pupils was at the optimal level in $19 \%$ of the pupils from the experimental groups (EG) and in 16\% in the control group (CG); at the sufficient level - in $28 \%$ of the EG and $27 \%$ of the CG; and at the critical level - in $53 \%$ of the EG and $57 \%$ of the CG (cf., Figure 2).

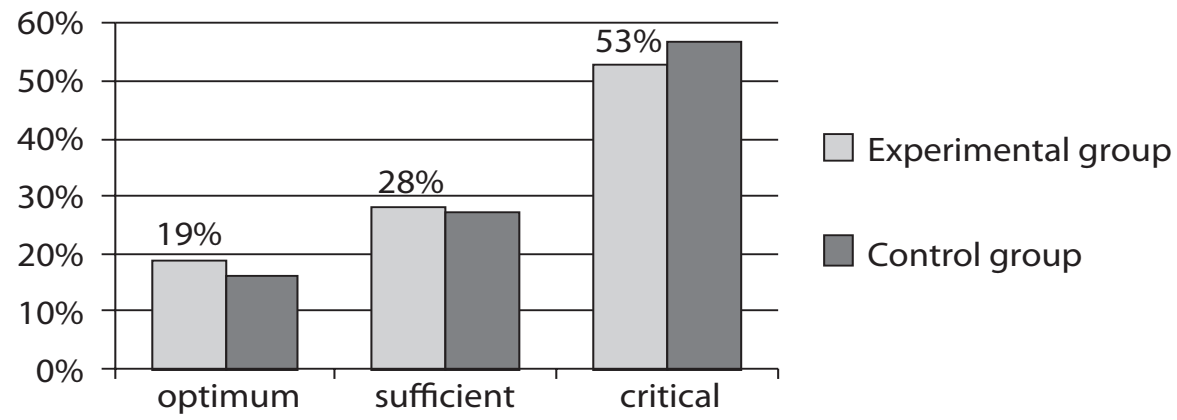

Figure 2. Results of the evaluation of the regulatory skills level in younger school pupils Source: Based on the author's design 
The documentation analysis method revealed the real opportunities of the modern educational programs of the subjects and school textbooks in the regulatory skills development in younger school students (Educational program of the general-education field subjects "Mathematics" for the $1^{\text {st }} 4^{\text {th }}$ grades of general-education schools, 2013). The conducted analysis of the tasks from the new-generation textbooks in mathematics, the Russian language and literature shows that various tasks are mostly aimed at developing only some of the regulatory skills and mostly at the level of executive actions. Because of this we developed the tasks for the group of regulatory skills in the Russian language and mathematics for independent individual solving.

\section{Discussion}

The developed Program was relatively efficiently evaluated, which is confirmed by the obtained monitoring results.

Firstly, primary school teachers' theoretical and methodological education had improved by the end of the experiment due to the complex goal-directed work on increasing teachers' professional competence in the field of regulatory skills development in younger school pupils. We conducted educational seminars on the basis of the regional and city scientific-practical centers of Aktobe. The result of the teachers' education was an increase in their professional competence in the field of the studied problem. The teachers of the experimental groups, upon learning the main methodological recommendations on the presented problem, started active participation in regulatory skills development in younger school pupils. Increase in methodological training was also facilitated by individual consultations, the content of which included the discussion of planned questions, as well as the questions which occurred during the process of regulatory skills development in younger school children. The novelty for the teachers was the didactic opportunities of a methodological set of educational management (Management in the field of education, 2014) and game-technical management (Game-technical management, 2003) in the process of regulatory skills development in younger school pupils in the conditions of general-education schools.

Secondly, the activity of parents' participation in pupils' regulatory skills development during the extra-curricular time increased. The cooperative work of teachers and parents implied the discussion about the main questions of the studied pedagogical problem during parent meetings, which were conducted according to the school plan. The parents obtained the information on all the main 
issues of the presented problem - "The role of regulatory skills in the educational and cognitive activity of the pupils", "Time-management for younger school pupil”, "Regulatory skills development in younger school pupils during extra-curricular time" - in the form of lectures, discussions, active hand-out materials and practical recommendations.

Thirdly, the motivation and quality of the educational activity self-regulation in pupils also increased because of the work on regulatory skills development in the framework of the education system, which included the development and conduction of classes on the topic of the studied problem. At the beginning of the experiment, eight topics were included in the calendar schedules of the classes and mentoring events, and throughout the experiment these classes were held in the experimental groups.

The system of regulatory skills development in younger school students is based on the activity theory by A.N. Leontyev (2004), according to which the activity is a system which has its structure, its internal transfers and transformations and its own development. In reality, the subject of educational activity regulation is its content and its reflection in the subject's conscience. Viewing the educational activity from the perspective of A. Leontyev's activity theory presents it as its certain type, which consists of a number of actions. These actions are single acts of transformation which consist of operations - elemental transformation acts, the results of which are not recognized by the subject as an independent goal. In such a case, educational activity regulation can be described by the same structure: activity - actions - operations.

We suppose that the actions that provide younger school pupils' educational activity regulation include a number of operations, unified by their form: orientation, planning, execution and control. The technological structure of the model of educational activity regulation in younger school pupils has three blocks - entrance (the beginning of the pupil's educational activity regulation), the module block (which is composed of five consequent separate modules actions with the same structure but different contents: operations of orientation, planning, execution and control) and exit (the end of the pupil's educational activity regulation).

We defined the content of each operation in the regulation actions and obtained full complex content of regulatory skills:

1. Goal definition - defining and reviewing the activity object, defining the requirements, conditions and rules of obtaining the result, conducting the process of understanding the activity type and defining the personality opportunities in the chosen activity type; 
2. Planning - defining the main operations, setting the order and the sequence of operations, defining a rational way of educational activity execution, comparing the plan, educational activity execution tools and one's own personality opportunities;

3. Goal-directed execution - considering the conditions and educational task plan, comparing the conditions and educational task plan with the performed operations, executing the task completely, obtaining the result, checking whether the obtained proportion is correct, correction of unsuccessful actions;

4. Control of the activity process and results - specifying the content of the obtained result, searching for a sample for comparison; choosing the way for the result evaluation depending on its content; evaluation executing in the chosen way, comparing the obtained results with the sample; defining the opportunities to execute the educational task in any other way, specifying the reasons for missing the goal;

5. Orientation of the activity process and results - specifying evaluation criteria, choosing a way of result evaluation, evaluation executing, comparing evaluation criteria with the obtained results, personal evaluation with the normative criteria, correction of the evaluation actions.

The content of educational activity regulation operations provides the content of the developed skills. The structure of educational activity regulation, which is presented as a number of actions, operations and operation content, is a complex orientation basis of the activity (OBA). Orientation basis of the activity is a system of a person's representations of the goal, plan and means of executing prospective or present actions (the term was introduced by P.Ya. Galperin). Describing the OBA by highlighting all of the actions and operations corresponds to the complete sequential algorithm structure of the educational activity execution. A folded algorithm structure (OBA) is the description of regulatory skills through the named regulatory actions. As the experiment results demonstrate, the defined orientation basis of educational activity regulation provides the development of regulatory skills to the level of the generalized way of educational activity regulation in the condition of the complete acquisition of the OBA by younger school pupils. 


\section{Conclusions}

Thus, the process of the regulatory skills development process in younger school pupils is conducted from the moment of the children's admission to primary school and, as the experiment results show, is highly dependent of the educational program chosen by the teacher. Regulatory skills, being the core components of educational activity, are gained by the younger school pupils as constant skills, which become the basis for learning other educational abilities and skills and for solving any subject educational tasks.

In contrast to other scientific developments in the present problem, the novelty of our Program consists of:

- special program of scientific and methodological education of teachers for regulatory skills development in younger school students (a cycle of education seminars and individual consultations);

- system of regulatory skills development in younger school students (by means of classes and mentoring systems, as well as methodological work);

- cooperative activity of teachers and parents, aimed at the solution of the stated problem.

The result of the evaluation of the presented Program for regulatory skills development in younger school children in the school educational process is the occurrence of the need to integrate certain changes in the current primary-school education system, which, in turn, might be significant even for the international pedagogical science and practice. The main changes are:

1. Younger school pupils' educational activity is initially organized and regulated by them, according to the algorithm of the generalized way of educational activity organization (in the aspect of our study).

2. The object of special learning by younger school children becomes the knowledge of educational task goals, education tasks plans, types of control and evaluation and the sequence of educational activity regulation. The need for mastering them is understood as a special educational task. The complex of the developed special tasks, which correspond to the present algorithm in mathematics and the Russian language, was successfully evaluated.

3. The connection of content and operation knowledge for each of the regulatory skills proceeds sequentially; children separate regulatory actions in the process of the educational activity regulation. They learn the educational activity of modelling the stages of self-organizing during various educational tasks execution, which allows for observing and understanding their consistency and independence of the educational tasks subjective content. 
Thus, the conducted theoretical and analytical work on the present problem allowed us to confirm the scientific significance of our study, to express our opinion on the problem of regulatory skills development in school pupils, to develop a structural-functional model of regulatory skills development in younger school students and to successfully evaluate the developed Program of regulatory skills development in younger school children in the conditions of pedagogical experiment. Based on the results of the experimental work, we plan to develop and publish an educational-methodological textbook on the present study problem for the students of pedagogical colleges and primary school teachers.

\section{References}

Deitering, F.G. (1995). Selbstgesteuertes Lernen. (Self-oriented learning). Göttingen: Verlag für Angewandte Psychologie.

Dietrich, S. (1999). Selbstgesteuertes Lernen auf dem Weg zu einer neuen Lernkultur (Self-directed learning on the way to a new learning culture). Frankfurt am Main.

Faulstich, P. (1999). Einige Grundfragen zur Diskussion um «selbstgesteuertes Lernen» (Some basic questions to the discussion on «self-directed learning») In Selbstgesteuertes Lernen auf dem Weg zu einer neuen Lernkultur (Self-directed learning on the way to a new learning culture). Frankfurt am Main, pp. 24-39.

Friedrich, H.F. (1995). Analyse und Förderung kognitiver Lernstrategien (Analysis and promotion of cognitive learning strategies). Empirische Pädagogik, 9(2): 115-153.

Gosudarstvennaya programma razvitiya obrazovaniya Respubliki Kazakhstan na 2011-2020 gody ot 7 dek. 2010 goda № 1118. (State Program for the Development of Education of the Republic of Kazakhstan for 2011-2020 of Dec 7. 2010 № 1118). (2010). Astana.

Gosudarstvennyy obscheobyazatelnyi standart srednego obrazovaniya (nachalnogo, osnovnogo srednego, obschego srednego obrazovaniya) (State obligatory standard of secondary education (primary, basic secondary, general secondary education). (2012). №1080 (GOSO RK 1.4.002, Astana.-2012).

Igrotekhnicheskiy menedzhment. Interaktivnye tekhnologii dlya obucheniya i organizatsionnogo razvitiya personala: Uchebnoe posobie. (Game-technology management. Interactive technologies for training of personnel and organizational development). Saint-Petersburg: IVESEP, “Znanie”, $536 \mathrm{~s}$.

Knisarina, M.M. (2015). Preemstvennost standartov obschego i pedagogicheskogo obrazovaniya Respubliki Kazakhstan $v$ kontekste problem formirovaniya upravlencheskikh umeniy mladshikh shkolnikov. Sbornik materialov Vserossiyskoy mezhdunarodnoy konferentsii "Nepreryvnoe pedagogicheskoe obrazovanie v sovremennom mire: ot issledovatelskogo poiska $k$ productivnym resheniyam. Obrazovatelnyy protsess $v$ vuze $v$ usloviyakh vnedreniya obrazovatelnykh professionalnykh standartiv" (Eligibility standards for general and pedagogical education of the Republic of Kazakhstan in the context of the problems of the formation of administrative abilities of younger schoolboys. Collection of 
proceedings of the international conference "The continuous pedagogical education in the modern world: from research to find productive solutions. The educational process in high school in the conditions of the implementation of educational Occupational Standards"), Sankt-Petersburg, 25 March 2015, pp. 36-38.

Knisarina, M.M. (2015). Rol upravlencheskikh umeniy v uchebno-poznavatelnoy deyatelnosti mladshego shkolnika. (The role of management skills in teaching and cognitive activity of the younger schoolboy), Khabarshy-Vestnik Evraziyskogo natsionalnogo universiteta im. L.N. Gumileva (Khabarovsk-Bulletin of the Eurasian National University. LN Gumilyov), 3: 82-85.

Kraft, S. (2001). Selbstgesteuertes Lernen in der Weiterbildung (Self-directed learning in training). Hohengehren, Schneider Verlag, pp. 76-79.

Leontev A.N. (2004). Deyatelnost. Soznanie. Lichnost. (Activities. Consciousness. Personality) Moscow: Smysl; Akademia, 346 p.

Naribaev, K.N., Aganina, K.Zh., Nurlikhina, G.B., Utebaeva, G.B., Zhunusbekova, A., Knisarina, M.M. (2014). Menedzhment v sfere obrazovaniya: Uchebnoe posobie (Management in education). Almaty: KazNU imeni Abaya: Izd-vo "Ulagat", 216 p.

National development of functional literacy action plan for students for 2012-2016. (2012). Number 832 of 25 June 2012, Astana.

Learning: The Treasure (Learning: See Treasure Within). Summary of the Report of the International Commission on Education for the $21^{\text {st }}$ century. Retrieved from: http:// www.ifap.ru/library/book2011.pdf.

Reischmann, J. (2002). Selbstgesteuertes Lernen: Entwicklung des Konzepts und neuere theoretische Ansätze (Self-directed learning: development of the concept and recent theoretical approaches). Schneider Verlag, Hohengehren, 107-126 p.

Sadvakasova, Z.M. (2012). Pedagogicheskiy menedzhment. Uchebnoe posobie (Teaching Management. Tutorial). Almaty, $187 \mathrm{p}$.

Shiyanov, E.N., Kotova, I.B. (1999). Razvitie lichnosti v obuchenii: Uchebnoe posobie dlya studentov pedagogicheskikh vuzov (Development of the person in training: A manual for students of pedagogical universities). Moscow.

Tatyachenko, D.V., Vorovschikov, S.G. (2003). Razvitie obscheuchebnykh umeniy shkolnikov (The development of general educational abilities of schoolboys). Narodnoe obrazovanie, 8: 115-126.

Uchebnaya programma po predmetam obrazovatelnoy oblasti "Matematika" dlya 1-4 klassov obscheobrazovatelnoy shkoly (The curriculum in the subjects of educational area "Mathematics" for the $1^{\text {st }} 4^{\text {th }}$ grades of a comprehensive school). (2013). Astana, $19 \mathrm{p}$.

Weinert, F.E. (1996). Für und Wider die „neuen Lerntheorien“ als Grundlagen pädagogisch-psychologischer Forschung (Pros and cons of the "new learning theories" as bases of pedagogical-psychological research). Zeitschrift für Pädagogische Psychologie (Journal of Educational Psychology), 10 (1): 1-12. 